\title{
Morphology by Grafted Cell of Spinal Cord Region from Infarction Surgery
}

\section{Tae Hoon Lee*}

Department of Emergency Medical Service, Namseoul University, Korea

\section{Introduction}

Recovery in central nervous system (CNS) disorders is hindered by the limited ability of the system to regenerate lost cells, replace damaged myelin, and re-establish functional neural connections. Cell transplants are being actively researched for treatment of CNS injuries. This study was undertaken to examine the effects of transplanted mouse embryonic stem cells (mESC) on spinal cord injuries in rats. The spinal cord injuries were produced by clip compression device. The transplants were made on the seventh day after the injuries. The injury areas of cavity volumes were smaller in the transplant group than they were for the non-transplant group. Immunohistochemical study revealed that the transplanted mESC infiltrated into the injured areas of the injuries, but the transplanted mESC were not differentiated into glial or neuronal cells. In the previous studies, no mESC was differentiated into GFAPpositive astrocytes or NF (or tubulin) positive neurons. Most mESC were of an undifferentiated cell type. Neural stem/progenitor cells (NSPCs) have previously been identified in both the mammalian brain and spinal cord. Non-transplant animals with BBB scores less than 7 showed the formation of large cavities. The spinal cords of mESC-transplant animals had cavities much smaller than those of non-transplant animals. These results suggested that mESC-transplant reduced the formation of cavities after injury in the SCI model. Considering that mESC can be used for autologous transplant, the results of the present study suggest that the transplant of mESC may be used for the treatment of spinal cord injuries [1-4].

\section{Conclusion}

It is important to prevent damage to the brain or other life-critical organs through prevention of complications such as respiration, circulatory failure and so on. These measures include the management of respiratory and circulatory systems, the treatment of body temperature abnormalities, the treatment of urination and defecation disorders, and the treatment of spinal cord. The mechanism of neuronal damage after spinal cord ischemia can be classified into two groups according to the timing. The initial neuronal cell damage is due to energy deficiency due to depletion of oxygen and glucose in blood flow restricted tissue, mass inflow of cations such as calcium due to changes in cell membrane permeability, It is caused by acidification, cell edema, protein denaturation, and accumulation of glutamate at neuronal junctions, and cells eventually become necrotic. Late neuronal cell death is a delayed neuronal death in the spinal cord region and T9 to T10 of thoracic nerve area which is transient ischemic 3-4 days. As a result, in the control group, injuries occurred in almost all areas where thoracic spinal cord is responsible for blood supply, whereas the injured areas in the experimental group were reduced. In comparison of the formation of cavity, it was found that the degree of cavitation in the experimental group was smaller than that of the control group. These results suggest that mouse embryonic stem cells reduce the volume of the infarction region of injury induced by reversible spinal cord ischemia in rats and have a protective effect against neuronal injury at the periphery of injury [5-8].

\section{References}

1. Basso DM, Murray M, Goldberger ME (1994) Differential recovery of bipedal and over ground locomotion following complete spinal cord hemisection in cats. Res Neurol Neurosci 7: 95-110.

2. Euler MV, Seiger A, Sundstrom E (1997) Clip compression injury in the spinal cord: A correlative study of neurological and morphological alterations. Exp Neurol 145: 502-510.

3. Joshi M, Fehlings MG (2002) Development and characterization of a novel, graded model of clip compressive spinal cord injury in the mouse. J Neurotrauma 19: 175-190.

4. Lankhorst AJ, Verzijl MR, Hamers FP (1999) Experimental spinal cord contusion injury: Comparison of different outcome parameters. Neurol Res Commun 24: 135-148.

5. Metz GA, Whishaw IQ (2002) Cortical and subcortical lesions impair skilled walking in the ladder rung walking test: A new task to evaluate fore- and hindlimb stepping, placing and co-ordination. J Neurosci Met 115: 169-179.

6. Namiki J, Tator $\mathrm{CH}$ (1999) Cell proliferation and nestin expression in the ependyma of the adult rat spinal cord after injury. J Neuropathol Exp Neurol 58: $489-498$

7. Parr AM, Kulbatski I, Tator $\mathrm{CH}$ (2007) Transplantation of adult rat spinal cord stem/progenitor cells for spinal cord injury. J Neurotrauma 24: 835-845.

8. Svendsen CN, Smith AG (1999) Newprospects for human stem-cell therapy in the nervous system. Trends Neurosci 22: 357-364.
*Corresponding author: Tae Hoon Lee, Department of Emergency Medical Service, Namseoul University, Korea, E-mail: thlee@nsu.ac.kr

Received March 13, 2018; Accepted April 17, 2018; Published April 24, 2018

Citation: Lee TH (2018) Morphology by Grafted Cell of Spinal Cord Region from Infarction Surgery. Int J Neurorehabilitation 5: 311. doi: 10.4172/2376-0281.1000311

Copyright: ( $) 2018$ Lee TH, et al. This is an open-access article distributed under the terms of the Creative Commons Attribution License, which permits unrestricted use, distribution, and reproduction in any medium, provided the original author and source are credited. 